\title{
PENGEMBANGAN MODUL FISIKA BERORIENTASI PADA MODEL MOTIVASI ARCS (ATTENTION, RELEVANCE, CONFIDENCE,SATISFACTION) POKOK BAHASAN SUHU DAN KALOR SISWA KELAS X SMA
}

\author{
Riki Neneng Fadilah ${ }^{1}$, Fahmi Yahya ${ }^{2}$, A. Hamid Rahman ${ }^{3}$ \\ ${ }_{1,2,3}$ Prodi Pendidikan Fisika UNSA \\ Email: rikinenengfadilah@gmail.com
}

\begin{abstract}
Abstrak
Membuat siswa tertarik, senang, belajar mandiri dan memahami materi fisika, memerlukan adanya buku ajar yang sesuai dengan kondisi dan tingkat pengetahuan siswa. Buku ajar tersebut adalah modul berorientasi pada model motivasi ARCS. Tujuan penelitian ini untuk mengetahui tingkat kelayakan, keterbacaan, dan respon siswa terhadap modul fisika yang dikembangkan. Jenis penelitian ini adalah penelitian dan pengembangan level 1 dengan menggunakan 8 dari 10 langkah penelitian dan pengembangan Borg \& Gall. Uji kelayakan modul dilakukan oleh validator ahli materi dan media serta guru fisika. Uji keterbacaan dan respon siswa dilakukan pada uji coba kelompok kecil dan kelompok besar. Hasil penelitian menunjukkan bahwa tingkat kelayakan modul pada aspek materi sebesar $87,4 \%$ dan $87,5 \%$ pada aspek media dengan kategori sangat layak. Tingkat keterbacaan modul pada uji coba kelompok kecil sebesar 98,4\% dan 99,3\% pada uji coba kelompok besar dengan kategori keterbacaan tinggi. Respon siswa terhadap modul pada uji coba kelompok kecil sebesar 90,9\% dan 91,9\% pada uji coba kelompok besar dengan kategori sangat baik.
\end{abstract}

Kata Kunci: Modul Fisika, Model Motivasi ARCS, Suhu dan Kalor.

\section{PENDAHULUAN}

Komponen utama yang harus dipenuhi dalam proses belajar mengajar yaitu, tujuan, bahan ajar, metode dan alat, serta penilaian pengajaran (Sudjana, 2013:30). Tujuan pembelajaran akan tercapai jika informasi berupa materi pelajaran yang diberikan guru dapat dipahami dengan baik oleh siswa, karena hakikat proses belajar mengajar adalah komunikasi. Mempermudah guru dalam menyampaikan materi dan siswa untuk mempelajari materi tersebut, maka guru perlu mengorganisasikan materi ke dalam bahan ajar (Yogica, 2014). Bahan ajar adalah materi yang diberikan kepada siswa berupa fakta, prinsip, konsep, dan ketrampilan sesuai dengan kurikulum, guna mendukung tercapainya tujuan atau tingkah laku yang diharapkan dimiliki oleh siswa (Sudjana, 2013: 67).

Hal penting yang harus dikuasai guru adalah mampu menyediakan bahan ajar yang dapat dipelajari sendiri oleh siswa, dan memberikan kesempatan kepada siswa untuk mengukur perilaku belajarnya tanpa harus ada campur tangan guru. Bahan ajar merupakan komponen sistem pembelajaran yang memegang peranan penting dalam membantu siswa mencapai Standar Kompetensi (SK) dan Kompetensi Dasar (KD) (Mudlofir, 2011:125). Selain itu, bahan ajar juga menjadi salah satu faktor yang dapat guru gunakan untuk meningkatkan motivasi belajar siswa, karena bahan ajar merupakan faktor eksternal siswa yang memperkuat motivasi internal untuk belajar (Saputra, dkk., 2014). Di sisi lain, pelaksanaan kegiatan pembelajaran saat ini lebih banyak dilakukan secara klasikal, dimana semua siswa dianggap sama dalam segala hal baik kemampuan, gaya belajar, kecepatan pemahaman, motivasi belajar, dan sebagainya. Padahal fakta menunjukan bahwa karakteristik siswa berbeda antara satu siswa dengan siswa yang lain. Perbedaan karakteristik siswa sering diabaikan oleh guru dalam proses pembelajaran (Wena, 2012:224).

Bahan ajar yang bersifat individual dan dapat mengiringi perbedaan karakteristik masing-masing siswa, sehingga siswa dengan mudah memahami materi pelajaran, yaitu 
berupa modul (Yogica, 2014). Modul merupakan buku/bahan ajar berbentuk diktat yang ditujukan untuk keperluan pembelajaran secara mandiri (selfinstruction) (Akbar, 2015:33). Modul merupakan salah satu bahan ajar yang dapat membantu siswa maupun guru dalam proses pembelajaran, karena dengan modul siswa dapat mengajar dirinya sendiri dan melakukan kontrol sendiri terhadap intensitas belajarnya (Asfiah, dkk., 2013). Pembelajaran dengan modul memungkinkan siswa yang memiliki kecepatan tinggi dalam belajar akan lebih cepat menyelesaikan satu atau lebih kompetensi dasar dibandingkan siswa lainnya (Prastowo, 2014:107).

Model Motivasi ARCS (Attention, Relevance, Confidence, Satisfaction) merupakan model motivasi yang dikembangkan oleh Keller (1987) berdasarkan teori nilai dan harapan (expectancy value theory) yaitu menggunakan nilai (value) dan harapan positif untuk sukses (expectancy), yang kemudian dua kategori motivasi tersebut dikembangkan oleh Keller menjadi empat komponen yaitu attention, relevance, confidence, dan satisfaction. Pembelajaran dengan model ARCS adalah suatu bentuk pembelajaran yang mengutamakan perhatian siswa, menyesuaikan materi pembelajaran dengan pengalaman belajar siswa, menciptakan rasa percaya diri siswa, dan menimbulkan rasa puas dalam diri siswa pada proses pembelajaran (Lilies, 2013).

Fungsi pengajaran fisika diantaranya yaitu, siswa dapat menguasai pengetahuan fisika. Namun pengetahuan yang sudah dimiliki oleh guru fisika tidak dapat dipindahkan begitu saja kepada siswa. Pengetahuan hanya dapat ditawarkan kepada siswa untuk dibangun sendiri secara aktif oleh siswa itu sendiri (Suparno, 2013:15). Observasi penelitian yang telah dilakukan oleh Fitri, dkk. (2013) menunjukan bahwa, beberapa faktor yang menyebabkan pembelajaran fisika kurang maksimal adalah siswa merasa pembelajaran fisika membosankan dan kurang menarik karena pembelajaran masih berpusat pada guru, dimana siswa hanya mendengarkan, mengerjakan soal, dan mengerjakan tugas. Selain itu, pemahaman konsep dan hasil belajar fisika siswa juga relatif rendah. Salah satu materi fisika yang erat kaitannya dengan kehidupan sehari-hari yaitu materi suhu dan kalor. Materi tersebut dapat memberikan manfaat secara langsung dalam kehidupan sehari-hari siswa yang mampu menumbuhkan motivasi belajar (Lilies, 2013). Materi suhu dan kalor yang lebih banyak membahas tentang kejadian sehari-hari di lingkungan akan sulit dipahami siswa jika tidak disampaikan dengan baik oleh guru. Guna mempermudah proses pembelajaran yang membahas tentang sebuah kejadian yang sulit untuk dibayangkan oleh siswa, maka peran bahan ajar sangatlah penting (Pintara, dkk., 2013). Salah satu yang dapat dilakukan agar pembelajaran fisika lebih bermakna adalah guru mengembangkan bahan ajar berupa modul yang mampu membantu siswa dan guru dalam proses pembelajaran (Fitri, dkk., 2013).

Modul sebagai salah satu jenis bahan ajar harus memenuhi beberapa aspek, yaitu: akurasi, relevansi, komunikatif, lengkap dan sistematis, berorientasi pada student centered, memenuhi kaidah bahasa Indonesia yang benar, dan memiliki tingkat keterbacaan yang tinggi (Akbar, 2015:34). Berdasarkan aspek tersebut, peneliti melakukan tinjauan terhadap buku fisika yang digunakan oleh guru dan siswa kelas X di SMA Negeri 1 Sumbawa Besar. Hasil tinjauan buku guru dan siswa pada aspek akurasi, yaitu materi yang disajikan sesuai dengan kebenaran keilmuan, dan sesuai dengan kehidupan sehari-hari siswa, namun tidak semua konsep dijelaskan dengan contoh penerapannya dalam kehidupan. Sedangkan pada aspek relevansi, yaitu 1) materi, tugas, contoh-contoh penjelasan, latihan dan soal relevan dengan Standar Kompetensi (SK) dan Kompetensi Dasar (KD) yang telah ditetapkan kurikulum; 2) jabaran materi cukup memenuhi tuntutan kurikulum, namun tidak dijelaskan secara lengkap. Hal ini membuat siswa kurang memahami materi yang harus dikuasai secara utuh; 3) jumlah ilustrasi fungsional dalam buku masih kurang, karena tidak semua materi dijelaskan dengan menggunakan ilustrasi. Walaupun demikian, jumlah latihan, soal, dan tugas cukup dan dapat melatih kemampuan siswa.

Adapun hasil tinjauan terhadap buku guru dan siswa pada aspek komunikatif, yaitu bahasa yang digunakan dalam buku mudah dipahami oleh siswa. Sedangkan pada aspek 
kelengkapan dan sistematis yaitu, 1) buku ajar yang baik seharusnya mencantumkan kompetensi dasar yang harus dikuasai oleh siswa, namun buku yang digunakan siswa tidak menyajikannya, secara tidak langsung siswa tidak mengetahui kompetensi yang harus dicapai pada pembelajaran fisika; 2) selain itu buku ajar yang baik juga menyajikan manfaat dan pentingnya penguasaan kompetensi bagi kehidupan siswa dalam penjelasan materinya, menyajikan daftar isi dan daftar pustaka. Namun, buku ajar yang digunakan siswa dan guru tidak menyajikan manfaat dan pentingnya kompetensi tersebut, hanya menyajikan daftar isi dan daftar pustaka; 3) buku tidak dilengkapi dengan peta konsep, padahal dengan peta konsep siswa dapat mengetahui alur dan pokok materi yang akan mereka pelajari; 4) buku tidak dilengkapi dengan definisi istilah untuk menghindari kesalahan penafsiran terhadap istilah yang kurang dimengerti oleh siswa; 5) buku tidak dilengkapi dengan rangkuman materi untuk mengingatkan siswa kembali terhadap materi yang telah mereka pelajari; 6) tidak semua materi disajikan dengan gambar, jika materi disajikan dengan gambar, tetapi gambar tidak berwarna; 7) tata letak materi mudah dipahami, namun desain buku kurang menarik; 8) buku di lengkapi dengan ilustrasi, namun tidak semua ilustrasi ditampilkan pada materi yang membutuhkan analisis tinggi; dan 9) buku dilengkapi dengan pendidikan karakter untuk meningkatkan aspek afektif siswa, namun tidak semua materi fisika dilengkapi dengan Lembar Kegiatan Peserta Didik (LKPD) untuk membangun ketrampilan psikomotorik siswa, khususnya pada materi suhu dan kalor.

Adapun hasil tinjauan buku guru dan siswa pada aspek kesesuaian sajian dengan tuntutan pembelajaran yang terpusat pada siswa yaitu, 1) kurang mendorong rasa keingintahuan siswa walaupun terdapat kotak dialog untuk menumbuhkan rasa keingintahuan siswa; 2) kurang mendorong terjadinya interaksi siswa dengan sumber belajar, dan 3) kurang mendorong siswa untuk membangun pengetahuannya sendiri, 4) kurang mendorong siswa untuk mengamalkan isi bacaan. Hal ini disebabkan kemasan materi yang kurang menarik. Walaupun demikian, buku guru dan siswa yang digunakan cukup mendorong siswa belajar secara berkelompok. Sedangkan pada aspek kaidah bahasa yang benar, bahasa dalam buku ajar yang digunakan guru dan siswa cukup memenuhi tuntutan Ejaan Yang Disempurnakan (EYD).

Berdasarkan hasil tinjauan terhadap buku fisika yang digunakan guru dan siswa di SMAN 1 Sumbawa Besar maka dapat disimpulkan bahwa, penggunaan buku fisika guru dan siswa masih kurang membantu guru untuk mengajar dan siswa untuk belajar secara maksimal, sehingga diperlukan tambahan referensi lain untuk memenuhi kebutuhan materi yang akan dipelajari. Belum terpenuhinya sumber belajar yang dapat menarik perhatian siswa untuk belajar, mengakibatkan beberapa hal seperti: 1) rendahnya minat baca siswa terhadap buku fisika sebagai salah satu sumber belajar; 2) motivasi belajar fisika siswa rendah dan siswa kurang percaya diri ketika mengerjakan soal-soal fisika, menjadi salah satu faktor penyebab rata-rata hasil belajar fisika siswa masih berada dibawah 78 sebagai nilai Kriteria Ketuntasan Minimal (KKM). Hal ini menimbulkan rasa ketidakpuasan siswa terhadap pembelajaran fisika. Selain permasalahan pembelajaran fisika pada buku ajar, juga pada alokasi waktu pelaksanaan pembelajaran fisika yang tidak berjalan sesuai dengan rencana. Hal ini menyebabkan ketidaksesuaian antara alokasi waktu belajar dengan materi fisika yang harus siswa pelajari. Agar materi yang harus dikuasai siswa dapat selesai sesuai dengan waktu yang ditentukan, maka siswa harus belajar secara mandiri. Sehingga, pembelajaran di kelas dapat siswa gunakan untuk membahas materi yang belum siswa kuasai dengan baik.

Berdasarkan pemaparan di atas, maka penelitian ini bertujuan untuk mengembangkan bahan ajar berupa modul berorientasi pada model motivasi ARCS pokok bahasan suhu dan kalor untuk siswa kelas X SMA dengan tingkat kelayakan, keterbacaan, dan respon siswa yang baik. Modul yang berorientasi pada model motivasi ARCS diharapkan terjadi proses belajar mengajar yang menyenangkan, kondusif dan siswa tertarik serta senang belajar fisika, memahami materi fisika dengan baik, dan siswa mampu 
belajar secara mandiri dalam hal menyelesaikan setiap permasalahan yang terkait dengan pelajaran fisika.

\section{KAJIAN PUSTAKA}

Modul merupakan sebuah bahan ajar yang disusun secara sistematis dengan bahasa yang mudah dipahami oleh siswa sesuai dengan tingkat pengetahuan dan usia siswa, sehingga mereka dapat belajar secara mandiri dengan atau tanpa bantuan atau bimbingan yang minimal dari guru. Kemudian dengan modul, siswa juga dapat menilai atau mengukur sendiri tingkat kemampuan atau penguasaannya terhadap materi yang telah siswa pelajari sendiri. Pembelajaran dengan modul memungkinkan siswa dapat lebih cepat menyelesaikan satu atau lebih kompetensi dasar dibandingkan dengan siswa yang tidak menggunakan modul. Oleh karena itu, modul harus menggambarkan kompetensi dasar yang akan dicapai oleh siswa, serta disajikan dengan bahasa yang baik, menarik, dan dilengkapi dengan ilustrasi (Prastowo, 2014:106). Modul dapat dikembangkan dengan beberapa cara, yaitu: 1) adaptasi, 2) kompilasi, dan 3) menulis (Purwanto, dkk., 2007:1013).

Model ARCS memiliki beberapa keunggulan antara lain: 1) memberi petunjuk aktif dan memberi arahan tentang apa yang harus dilakukan oleh siswa; 2) cara penyajian materi dengan model ARCS dilakukan dengan cara menarik; 3) model motivasi yang diperkuat oleh rancangan bentuk pembelajaran berpusat pada siswa; 4) meningkatkan motivasi untuk mengulang kembali materi lainnya yang pada hakekatnya kurang menarik; dan 5) penilaian yang dilakukan menyeluruh terhadap kemampuan-kemampuan yang lebih dari karakteristik siswa agar strategi pembelajaran lebih efektif (Winaya, dkk., 2013).

Ketika benda yang bersuhu panas menyentuh benda yang bersuhu dingin, maka akan terdapat adanya aliran energi yang diberikan dari benda yang bersuhu tinggi ke benda yang bersuhu rendah. Energi yang berikan karena perbedaan suhu antara dua buah benda disebut kalor. Sedangkan suhu (temperatur) merupakan ukuran mengenai panas atau dinginnya benda (Giancoli, 2001:451-452,489). Beberapa aspek yang berkaitan dengan suhu dan kalor yaitu kapasitas kalor, kalor jenis, perubahan fase dan wujud zat, pemuaian, dan asas Black.

\section{METODE PENELITIAN}

Jenis penelitian yang dilakukan adalah penelitian dan pengembangan level 1 dan menggunakan 8 dari 10 langkah penelitian dan pengembangan Borg \& Gall, yaitu 1) penelitian dan pengumpulan informasi, 2) perencanaan, 3) pengembangan produk awal, 4) uji coba pendahuluan, 5) revisi produk awal, 6) uji coba terbatas, 7) revisi produk operasional, dan 8) uji coba produk. Penelitian ini terdiri atas uji kelayakan modul yang dilakukan oleh 1 orang ahli materi, 1 orang ahli media, dan 3 orang guru fisika; uji keterbacaan dan respon siswa terhadap modul yang dilakukan oleh 10 orang siswa kelas X MIA 5 pada uji coba kelompok kecil dan 39 orang siswa kelas X MIA 2 pada uji coba kelompok besar.

Tahap penelitian dan pengumpulan informasi, peneliti melakukan analisis kebutuhan seperti: a) observasi non-sistematis terhadap kegiatan pembelajaran fisika siswa, karena dilakukan tanpa menggunakan instrument pengamatan; b) wawancara dengan guru dan siswa mengenai masalah dalam pembelajaran, c) analisis kurikulum untuk menghasilkan indikator dan tujuan pembelajaran; d) analisis langkah-langkah pengembangan modul; dan e) review literatur untuk menentukan materi-materi yang akan dicantumkan dalam modul dan hasil-hasil penelitian yang telah dilakukan oleh peneliti sebelumnya yang relevan dengan produk yang peneliti kembangkan. Tahap perencanaan, peneliti membuat suatu perencanaan modul yang dituangkan dalam Garis-Garis Besar Isi Modul (GBIM). GBIM terdiri dari: a) judul modul, b) tujuan umum pembelajaran yang tertuang dalam kompetensi dasar, c) tujuan khusus pembelajaran yang tertuang dalam indikator pencapaian 
kompetensi, d) pokok bahasan atau pokok materi, e) rincian materi/sub-sub pokok bahasan, dan f) kepustakaan/sumber pustaka.

Tahap pengembangan produk awal, peneliti membuat format modul awal menggunakan teknik pengembangan modul kompilasi. Pengembangan modul dengan teknik kompilasi, yaitu dengan mengumpulkan seluruh kutipan teori-teori dari berbagai buku yang disesuaikan dengan kebutuhan peneliti (Purwanto dkk., 2007:11). Pengembangan modul awal selanjutnya diorientasikan dengan model motivasi ARCS, sehingga modul relevan dengan teori ilmu yang ada, siswa tertarik serta berminat (attention) untuk membaca, dan dalam prosesnya modul fisika ini diharapkan dapat menimbulkam confidence serta satisfaction dalam diri siswa pada proses pembelajaran fisika. Adapun bagian-bagian modul fisika yang peneliti kembangkan sebagai berikut.

a. Bagian pendahuluan terdiri dari: halaman sampul, halaman francis, kata pengantar, daftar isi, petunjuk penggunaan modul, pemetaan Kompetensi Inti (KI) dan Kompetensi Dasar (KD), dan peta konsep.

b. Bagian utama terdiri dari: kegiatan belajar 1, kegiatan belajar 2, kegiatan belajar 3, kegiatan belajar 4, dan kegiatan belajar 5. Kegiatan belajar 1 s.d 4 terdiri atas: tujuan pembelajaran umum dan khusus, alokasi waktu, motivasi belajar, kata kunci, uraian materi, contoh-contoh, ilustrasi atau diagram, tabel, tahukah kamu, ayo kita lakukan, ayo kita bermain, review, ayo kita diskusikan, ayo kita pahami, karakter anak bangsa yang baik, ayo kita renungkan, petunjuk, tokoh, rangkuman, latihan soal dan refleksi. Sedangkan kegiatan belajar 5 berupa evaluasi akhir yang terdiri atas soal pilihan ganda dan uraian.

c. Bagian penutup terdiri dari: daftar pustaka, daftar istilah, kunci jawaban, catatan, dan profil penulis.

Berikut beberapa langkah pengembangan modul fisika berorientasi pada model motivasi ARCS sesuai pada Tabel 1.

Tabel 1. Pengembangan Modul Berorientasi pada Model Motivasi ARCS

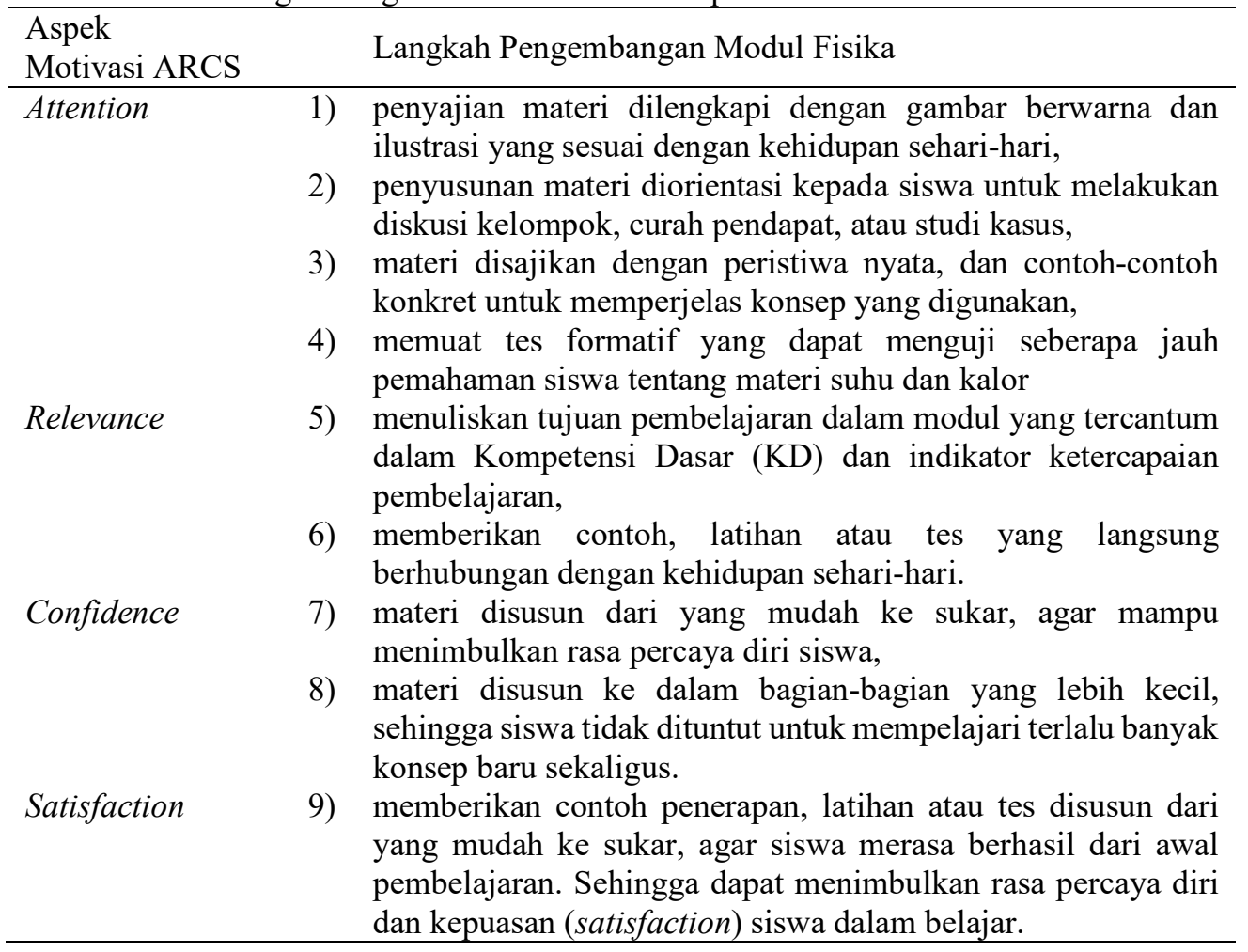


Tahap uji coba pendahuluan, peneliti menyerahkan modul awal yang telah peneliti kembangkan kepada ahli isi/materi, ahli media/instruksional, dan guru bidang studi fisika untuk di uji kelayakannya menggunakan angket. Bidang yang dikomentari yaitu isi/materi, dan media/instruksional. Pada tahap ini, peneliti memperoleh informasi kelebihan dan kekurangan dari modul, yang selanjutnya dijadikan sebagai bahan untuk merevisi modul. Tahap revisi produk awal, dilakukan berdasarkan hasil uji coba pendahuluan, berupa penilaian, komentar dan saran-saran para ahli dan guru fisika. Hasil revisi modul kemudian diserahkan kembali kepada ahli isi/materi, ahli media/instruksional, dan guru bidang studi fisika untuk di uji kelayakannya. Apabila modul dinyatakan valid dan layak digunakan, peneliti akan menguji coba modul pada uji coba terbatas.

Tahap uji coba terbatas, dilakukan untuk mengetahui tingkat keterbacaan dan respon siswa terhadap modul yang peneliti kembangkan dengan jumlah siswa terbatas (uji coba kelompok kecil). Mereka diminta untuk mengisi tes rumpang seputar wacana yang terdapat dalam modul dan memberikan penilaian terhadap penyajian/tampilan modul yang peneliti kembangkan menggunakan angket.

Tahap revisi produk operasional, dilakukan berdasarkan hasil pengujian produk pada uji coba terbatas. Revisi produk dilakukan berdasarkan hasil yang didapatkan dari penilaian, komentar, dan saran dari para siswa pengguna. Hasil revisi produk operasional dilakukan untuk memperbaiki modul agar menghasilkan modul yang lebih baik sebelum uji coba produk operasional. Tahap uji coba produk operasional, merupakan langkah terakhir dari penelitian dan pengembangan yang peneliti lakukan. Tahap ini hampir sama dengan tahap uji coba terbatas, yaitu untuk mengetahui tingkat keterbacaan dan respon siswa terhadap modul, hanya saja dilakukan oleh siswa dengan jumlah yang lebih besar.

Penilaian kelayakan dan respon siswa terhadap modul menggunakan angket berskala Likert, dan di analisis dengan rumus perhitungan nilai rata-rata. Sedangkan penilaian yang digunakan untuk mengetahui tingkat keterbacaan modul menggunakan tes rumpang dan di analisis dengan rumus perhitungan nilai rata-rata.

\section{HASIL DAN PEMBAHASAN}

Kelayakan modul dinilai dari aspek materi dan media. Uji kelayakan modul pada aspek materi dilakukan oleh 1 orang ahli isi/materi dan 3 orang guru fisika. Sedangkan uji kelayakan modul pada aspek media dilakukan oleh 1 orang ahli media/instruksional dan 3 orang guru fisika. Total persentase penilaian kelayakan modul pada aspek materi sebesar $87,4 \%$, sedangkan pada aspek media sebesar $87,5 \%$, yang berarti modul fisika berorientasi pada model motivasi ARCS termasuk dalam kategori sangat baik/layak.

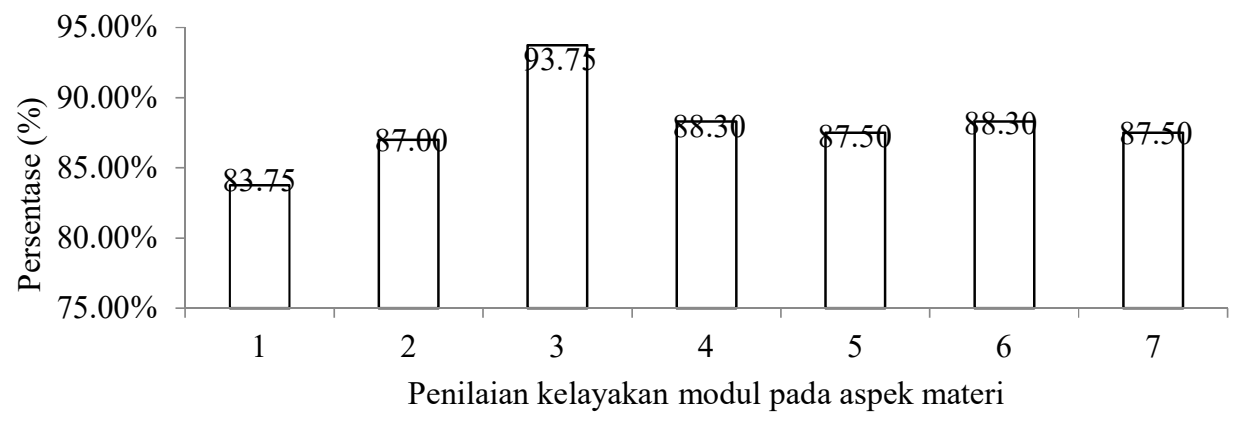

Gambar 1. Analisis Data Hasil Uji Kelayakan Modul pada Aspek Materi

Keterangan:

$1=$ Relevansi $\quad 5=$ Kesesuaian Sajian dengan Tuntutan Pembelajaran

$2=$ Keakuratan yang Terpusat pada Siswa

$3=$ Kelengkapan Sajian $\quad 6=$ Kebahasaan

$4=$ Sistematika Sajian $\quad 7=$ Keterbacaan 
Penilaian kelayakan modul pada aspek materi tercantum pada Gambar 1. terdiri atas 7 aspek materi, yaitu: 1) relevansi dengan persentase kelayakan sebesar $83,75 \%$ yang berarti memiliki kategori baik; 2) keakuratan sebesar 87,00\%, 3) kelengkapan sajian sebesar $93,75 \%, 4$ ) sistematika sajian sebesar $88,30 \%, 5$ ) kesesuaian sajian dengan tuntutan pembelajaran yang terpusat pada siswa sebesar $87,50 \%$,6) kebahasaan sebesar $88,30 \%$, dan 7) keterbacaan dan kekomunikatifan sebesar $87,50 \%$, yang berarti memiliki kategori sangat baik. Persentase penilaian kelayakan modul pada aspek materi dari masing-masing ahli materi, guru fisika 1, guru fisika 2, dan guru fisika 3 secara berurutan sebesar 96,4\%, $80,0 \%, 83,0 \%$, dan $90,3 \%$. Ahli materi dan guru fisika 3 menilai bahwa modul fisika pada aspek materi adalah sangat baik dan layak, yang berarti modul dapat digunakan tanpa revisi. Materi modul yang disajikan sudah baik, padat, memiliki alur pikir yang dapat mendorong minat, perhatian dan interaksi antar siswa secara berkelompok, serta mudah dipahami oleh siswa.

Guru fisika 1 dan 2 menilai bahwa modul fisika pada aspek materi adalah baik dan layak, yang berarti modul dapat digunakan dengan sedikit revisi. Guru fisika 1 mengemukakan bahwa point penting yang perlu ditambahkan adalah hasil eksperimen pada topik Ayo Kita Lakukan dalam modul guru harus diselaraskan dengan tujuan awal melakukan eksperimen. Selain itu proses penilaian juga dipengaruhi pandangan guru fisika 1, bahwa modul yang baik dan memenuhi syarat untuk dapat disebarluaskan adalah modul yang cara pengembangannya menggunakan teknik menulis bukan dengan teknik kompilasi. Sehingga, penilaian maksimal yang diberikan oleh guru fisika 1 pada setiap indikator aspek penilaian materi adalah 4 dari 5 poin maksimal. Sedangkan guru fisika 2 mengemukakan bahwa materi yang disajikan cukup lengkap dan sangat detail, sesuai menjadi bahan ajar mandiri untuk siswa. Konsep juga disajikan dengan runut, namun pada cara penggunaan modul harus diperjelas lagi. Selain itu, uji kompetensi (tes formatif dalam modul yang peneliti kembangkan) perlu ditambahkan dengan uji soal pemahaman konsep dan soal-soal berbentuk HOTS (High Order Thingking Skills).

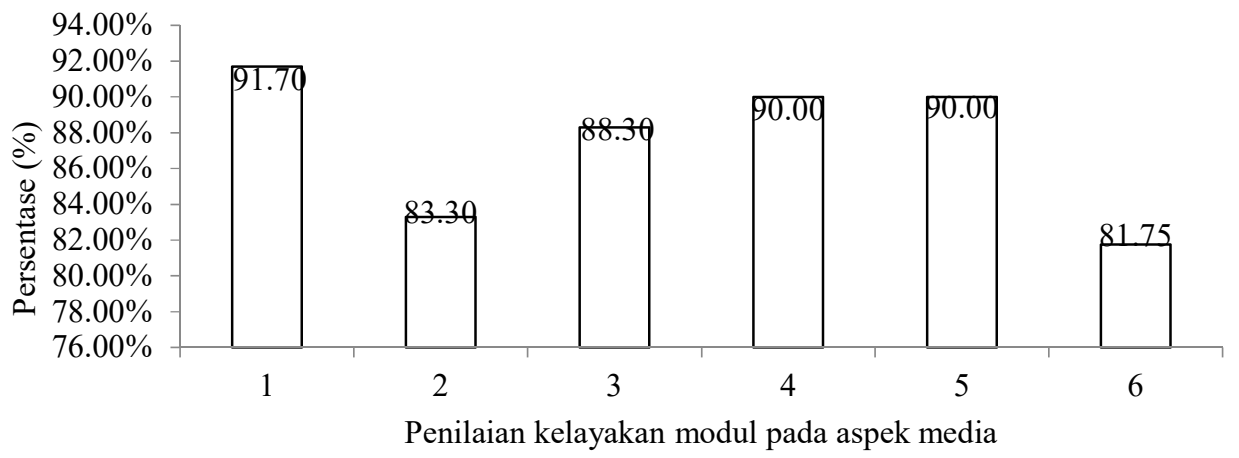

Gambar 2. Analisis Data Hasil Uji Kelayakan Modul pada Aspek Media

Keterangan:

$1=$ Desain

$2=$ Keterpaduan Materi

$4=$ Tipografi

$3=$ Ilustrasi/Gambar

$5=$ Layout

$6=$ Keterbacaan dan Kekomunikatifan

Penilaian kelayakan modul pada aspek media tercantum pada Gambar 2. terdiri atas 6 aspek media, yaitu: 1) keterpaduan materi dengan persentase kelayakan sebesar 83,30\%, dan 2) keterbacaan \& kekomunikatifan sebesar $81,75 \%$, yang berarti memiliki kategori baik, sedangkan 3) desain sebesar 91,70\%, 4) ilustrasi/gambar sebesar 88,30\%, 5) tipografi sebesar 90,00\%, dan 6) layout sebesar 90,00\%, yang berarti memiliki kategori sangat baik. Persentase penilaian kelayakan media modul dari masing-masing ahli media, guru fisika 1 , guru fisika 2, dan guru fisika 3 secara berurutan sebesar 83,3\%, 80\%, 92,2\%, dan 94,4\%. 
Ahli media dan guru fisika 1 menilai bahwa modul fisika dari aspek media adalah baik dan layak, yang berarti modul dapat digunakan dengan sedikit revisi. Ahli media memberikan nilai 4 dari 5 poin maksimal pada setiap indikator aspek keterpaduan materi, tipografi, dan keterbacaan \& kekomunikatifan. Penilaian tersebut mempengaruhi hasil penilaian kelayakan modul pada aspek media secara keseluruhan. Sedangkan guru fisika 1 memberikan poin maksimal 4 pada setiap indikator aspek media, karena pandangan guru fisika 1 bahwa modul yang baik dan memenuhi syarat untuk dapat disebarluaskan adalah modul yang cara pengembangannya menggunakan teknik menulis bukan dengan teknik kompilasi. Guru fisika 3 dan 4 menilai bahwa, modul fisika dari aspek media adalah sangat baik dan layak, yang berarti modul dapat digunakan tanpa revisi. Guru fisika 3 mengemukakan bahwa tampilan modul sangat menarik, namun penomoran halaman lebih baik menggunakan bahasa Indonesia. Sedangkan guru fisika 4 mengemukakan bahwa tampilan modul yang telah peneliti kembangkan relatif sangat baik, dapat digunakan siswa dalam mempermudah pemahaman materi suhu dan kalor.

Tingkat keterbacaan modul diketahui berdasarkan hasil tes rumpang yang telah dikerjakan oleh siswa. Hasil skor tes rumpang siswa kemudian dipadukan dengan kriteria tes keterbacaan menurut Rankin dan Culhane yang di adaptasi oleh Jatnika (2007). Jumlah soal tes rumpang secara keseluruhan sebanyak 45 soal. Uji keterbacaan modul dilakukan oleh 10 orang siswa pada uji coba kelompok kecil, dan 39 orang siswa pada uji coba kelompok besar. Persentase skor tes siswa pada uji coba kelompok kecil dan kelompok besar secara berurutan sebesar $98,4 \%$ dan $99,3 \%$. Besar persentase tersebut menunjukan bahwa, tingkat keterbacaan modul fisika berorientasi pada model motivasi ARCS baik pada uji coba kelompok kecil maupun kelompok besar tergolong dalam tingkat keterbacaan tinggi. Seluruh siswa baik pada uji coba kelompok kecil maupun kelompok besar mempunyai persentase skor tes yang jika dipadukan dengan kriteria uji keterbacaan Rankin dan Culhane yang di adaptasi oleh Jatnika (2007), menunjukan bahwa modul fisika yang telah peneliti kembangkan termasuk dalam tingkat keterbacaan tinggi. Siswa yang dapat mengerjakan semua soal tes rumpang dengan benar sebanyak 3 orang siswa pada uji coba kelompok kecil, dan 30 orang siswa pada uji coba kelompok besar. Berdasarkan proses berlangsungnya pelaksanaan uji keterbacaan modul baik pada uji coba kelompok kecil maupun kelompok besar, bahwa beberapa faktor yang menyebabkan siswa tidak bisa mengerjakan semua soal tes rumpang dengan benar yaitu: 1) siswa tidak fokus dengan wacana modul yang ia baca, dan 2) siswa mengerjakan tes rumpang sambil mengerjakan tugas lain yang menjadi kewajibannya.

Tingkat respon siswa terhadap modul fisika pada uji coba kelompok kecil dan kelompok besar secara berurutan sebesar $90,9 \%$ dan $91,9 \%$. Nilai persentase tersebut menunjukan bahwa siswa baik pada uji coba kelompok kecil maupun kelompok besar memberikan respon sangat baik, yang berarti modul fisika berorientasi pada model motivasi ARCS sangat disukai siswa sebagai sumber belajar siswa. Respon siswa terhadap modul terdiri atas 6 aspek, yaitu: 1) desain, dan 2) keterpaduan materi, 3) ilustrasi/gambar, 4) tipografi, 5) layout, dan 6) keterbacaan dan kekomunikatifan. Persentase ke enam aspek tersebut pada uji coba kelompok kecil secara berurutan sebesar 91,3\%, 85,3\%, 96,0\%, $92,7 \%, 89,0 \%$, dan $93,0 \%$, dan pada uji coba kelompok besar secara berurutan sebesar $91,1 \%, 88,2 \%, 96,7 \%, 92,3 \%, 90,3 \%$, dan $95,4 \%$, yang jika dipadukan dengan kriteria persentase skor respon siswa seluruhnya termasuk dalam kategori sangat baik. Hampir seluruh siswa baik pada uji coba kelompok kecil maupun kelompok besar mengemukakan bahwa modul didesain dengan menarik, full colour, dan materi yang disajikan mudah dipahami. Sehingga siswa berminat dan tidak bosan untuk membaca materi fisika. Namun beberapa siswa mengemukakan bahwa, desain cover modul agar dibuat lebih menarik lagi, dan perlu adanya penambahan soal latihan. Selain itu, apabila jenis gambar yang digunakan modul adalah kartun, maka sebaiknya seluruhnya menggunakan gambar kartun.

Berikut tampilan modul fisika berorientasi pada model motivasi ARCS dengan pokok bahasan suhu dan kalor untuk siswa kelas X SMA yang telah peneliti kembangkan. 

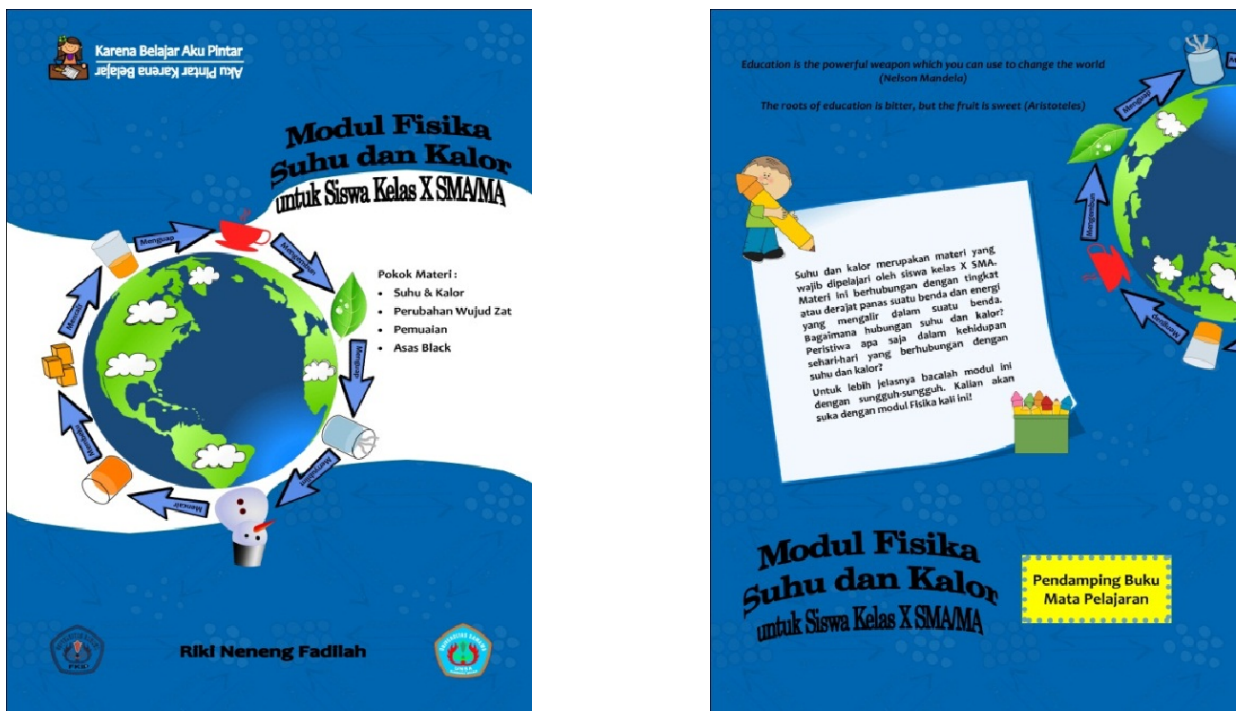

Gambar 3. Cover depan dan belakang modul fisika berorientasi pada model motivasi

\section{ARCS}
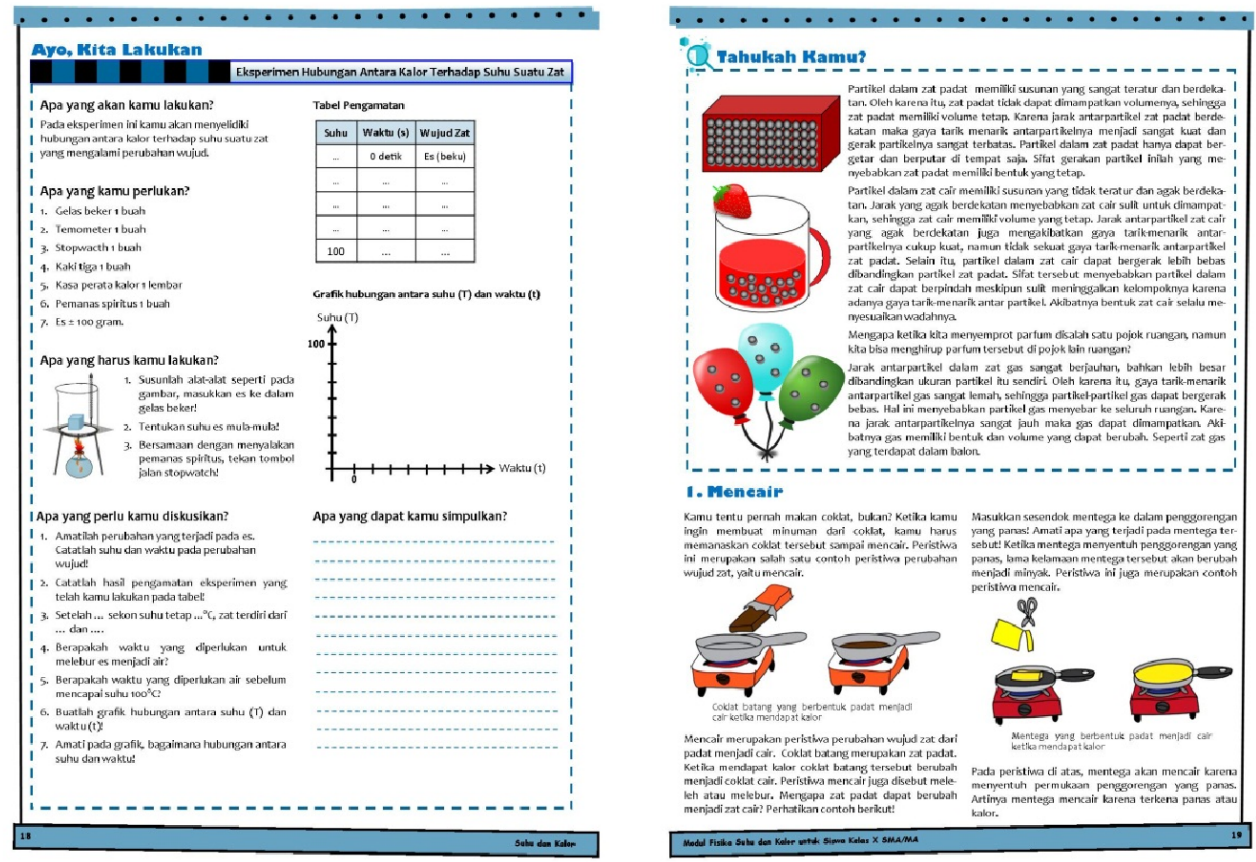

Gambar 4. Penyajian materi modul fisika berorientasi pada model motivasi ARCS

\section{SIMPULAN DAN SARAN}

Berdasarkan hasil penelitian dan pembahasan dapat disimpulkan bahwa, modul fisika berorientasi pada model motivasi ARCS (Attention, Relevance, Confidence, Satisfaction) pokok bahasan suhu dan kalor untuk siswa kelas X SMA dinilai sangat layak, memiliki tingkat keterbacaan tinggi, dan mendapat respon yang sangat baik dari siswa. Dengan demikian, modul fisika yang telah peneliti kembangkan dapat digunakan sebagai sumber belajar mandiri siswa kelas X SMA baik di sekolah maupun di luar lingkungan sekolah. 
Kelebihan modul fisika berorientasi pada model motivasi ARCS ini antara lain: a) modul dikembangkan dengan kurikulum terbaru yaitu kurikulum 2013; b) modul dilengkapi dengan fitur-fitur yang membuat siswa aktif dan belajar secara mandiri. Fiturfitur tersebut antara lain: 1) Review, fitur ini berfungsi untuk mengingatkan kembali materi yang sudah siswa pelajari, baik yang sudah dipelajari pada jenjang sebelumnya maupun materi yang baru siswa pelajari; 2) Tahukah Kamu?, fitur ini berfungsi untuk menambah pengetahuan siswa mengenai materi yang sedang siswa pelajari. Banyak hal-hal unik dan menarik yang disajikan dalam fitur ini; 3) Contoh Penerapan, fitur ini berfungsi untuk memberikan contoh penerapan materi dengan langkah-langkah yang lebih mudah dipahami oleh siswa; 4) Ayo, Kita Bermain, fitur ini berfungsi untuk mengajak siswa untuk berpikir lebih kreatif dan teliti untuk menjawab setiap pertanyaan yang diajukan; 5) Ayo, Kita Lakukan, fitur ini memberikan panduan eksperimen sederhana atau aktivitas untuk membantu siswa dalam memahami prinsip atau konsep. Aktivitas ini dapat dilakukan secara berkelompok di bawah bimbingan guru; 6) Ayo, Kita Pahami, fitur ini berisi uraian singkat konsep penting yang terkait dengan materi yang dipelajari siswa; 7) Ayo, Kita Diskusikan, fitur ini berisi suatu masalah yang berkaitan dengan konsep yang perlu untuk dipecahkan melalui diskusi kelompok. Fitur ini dapat melatih siswa dalam mengungkapkan pendapat atau berkomunikasi dan memecahkan masalah; 8) Ayo, Kita Selesaikan, fitur ini berisi soal-soal untuk mengetahui tingkat pemahaman siswa terhadap materi yang telah siswa pelajari; 9) Jendela Sains, fitur ini berfungsi untuk menambah wawasan siswa mengenai fenomena sains yang masih terkait dengan materi yang sedang siswa pelajari; 10) Ayo, Kita Renungkan, fitur ini berisi hal-hal yang berhubungan dengan Kebesaran Tuhan dan hal-hal yang perlu dihayati dan diterapkan dalam kehidupan sehari-hari; 11) Rangkuman, fitur ini berisi ringkasan materi dari setiap kegiatan belajar dalam modul. Siswa dapat mereview keseluruhan materi yang telah dipelajari melalui fitur ini; dan 12) Daftar Istilah, fitur ini berfungsi untuk mengingatkan kembali istilah-istilah pokok materi yang telah siswa pelajari dengan tampilan yang lebih menarik; c) penyajian materi dan tampilan modul didesain dengan menarik dan kreatif, full gambar dan full colour yang dapat menarik perhatian siswa untuk membaca; d) materi disajikan dengan peristiwa nyata, dan contoh-contoh konkret untuk memperjelas konsep yang digunakan, sehingga mampu menimbulkan attention siswa; e) materi disusun ke dalam bagian-bagian yang lebih kecil, sehingga tidak menuntut siswa untuk belajar materi yang harus dikuasainya sekaligus dalam satu waktu (mampu menimbulkan confidence siswa); dan f) latihan dan soal disusun dari mudah ke sukar, sehingga dari awal siswa merasa berhasil dan memupuk semangat siswa untuk mengerjakan soal dengan baik dan tuntas (mampu menimbulkan confidence dan satisfaction siswa terhadap pembelajaran fisika).

Kekurangan modul fisika berorientasi pada model motivasi ARCS ini antara lain: a) tingkat keterlaksanaan dan efektifitas modul dalam kegiatan pembelajaran fisika belum diketahui, b) modul fisika ini masih terbatas jumlahnya karena terkendala pada dana pencetakan, dan c) modul dikembangkan dengan teknik kompilasi, sehingga harus mendapatkan ijin dari pemegang hak cipta asli terhadap teori yang dikutip. Mengantisipasi masalah pada dana pencetakan dapat diatasi dengan memasarkan modul dalam bentuk file yang dapat siswa baca di handpond, ipad, notebook, atau laptop mereka. Sehingga, siswa dapat belajar fisika menggunakan modul ini tanpa harus mengeluarkan biaya yang lebih besar. Namun demikian, masalah permintaan ijin dari pemegang hak cipta aslinya dan uji kelayakan modul lebih lanjut membutuhkan proses yang dapat memakan waktu cukup lama.

Berdasarkan kekurangan modul fisika berorientasi pada model motivasi ARCS, maka dalam pengembangan selanjutnya agar dapat: a) menggunakan teknik menulis sehingga memenuhi syarat dalam penyebarluasan modul, b) menindaklanjuti saran revisi produk untuk menambahkan soal berbentuk HOTS (High Order Thingking Skills), dan c) mengadakan penelitian lanjutan untuk mengetahui tingkat keterlaksanaan dan keefektifan modul dalam proses pembelajaran fisika. 
DAFTAR PUSTAKA

Akbar, Sa'dun. 2015. Instrumen Perangkat Pembelajaran. Bandung: PT. Remaja Rosdakarya Offset.

Asfiah, Nailin, dkk.. 2013. Pengembangan Modul IPA Terpadu Kontekstual pada Tema Bunyi. Unnes Science Education Journal, 2 (1): 188-195.

Fitri, L. A., dkk.. 2013. Pengembangan Modul Fisika pada Pokok Bahasan Listrik Dinamis Berbasis Domain Pengetahuan Sains untuk Mengoptimalkan Minds-On Siswa SMA Negeri 2 Purworejo Kelas X Tahun Pelajaran 2012/2013. Jurnal Radiasi, 3 (1): 1923.

Giancoli, Douglas C.. 2001. Fisika Edisi 5 (Trj. Yuhiza Hanum). Jakarta: Erlangga.

Jatnika, A. W.. 2007. Tingkat Keterbacaan Wacana Sains dengan Teknik Klos. Jurnal Sosioteknologi, 10 (6): 196-200.

Keller, J. M.. 1987. Development and Use of the ARCS Model of Motivational Design. Journal of Instructional Development, 10 (3): 2-10.

Lilies. 2013. Strategi ARCS dalam Pembelajaran Biologi untuk Meningkatkan Motivasi Belajar Siswa. Prosiding Seminar Nasional Sains dan Matematika II Jurusan Pendidikan MIPA FKIP UNTA, A-13: 116-123.

Mudlofir, Ali. 2011. Aplikasi Pengembangan Kurikulum Tingkat Satuan Pendidikan dan Bahan Ajar Dalam Pendidikan Agama Islam. Jakarta: Rajawali Pers.

Pintara, G. J., dkk.. 2013. Pengembangan Metode Diskusi Foto Kejadian Fisika dalam Pembelajaran Pokok Bahasan Suhu dan Kalor pada Siswa SMA. Jurnal Pembelajaran Fisika, 2 (3): 356-362.

Prastowo, Andi. 2014. Panduan Kreatif Membuat Bahan Ajar Inovatif Menciptakan Metode Pembelajaran yang Menarik dan Menyenangkan. Yogyakarta : Diva Press.

Purwanto, dkk.. 2007. Pengembangan Modul. Jakarta: Departemen Pendidikan Nasional Pusat Teknologi Informasi dan Komunikasi Pendidikan.

Saputra, I W. A., dkk.. 2014. Pengembangan Bahan Ajar Fisika Materi Suhu dan Kalor Berbasis Budaya Masyarakat Trans Lalundu. Jurnal Pendidikan Fisika Tadulako, 1 (4): 54-60.

Sudjana, Nana. 2013. Dasar-Dasar Proses Belajar Mengajar. Bandung: Sinar Baru Algensindo.

Suparno, Paul. 2013. Metodologi Pembelajaran Fisika Konstruktivistik \& Menyenangkan. Yogyakarta: Universitas Sanata Dharma.

Wena, Made. 2012. Strategi Pembelajaran Inovatif Kontemporer Suatu Tinjauan Konseptual Operasional. Jakarta: Bumi Aksara.

Winaya, I M. A., dkk.. 2013. Pengaruh Model ARCS Terhadap Hasil Belajar Ditinjau dari Motivasi Belajar Siswa pada Pembelajaran IPS di kelas IV SD CHIS Denpasar. Jurnal Program Pascasarjana Universitas Pendidikan Ganesha Jurusan Pendidikan Dasar, 3.

Yogica, Relsas, dkk.. 2014. Efektifitas Modul Bergambar Disertai LKS Berorientasi Kontruktivistik Terhadap Proses dan Aktivitas Belajar Siswa dalam Pembelajaran Biologi SMA. Jurnal Pendidikan, 5 (1): 65-73. 